\title{
Front Matter: Volume 9895
}

"Front Matter: Volume 9895," Proc. SPIE 9895, Organic Photonics VII, 989501 (27 July 2016); doi: 10.1117/12.2244187

SPIE. Event: SPIE Photonics Europe, 2016, Brussels, Belgium 


\title{
PROCEEDINGS OF SPIE
}

\section{Organic Photonics VII}

\author{
David Cheyns \\ Pierre M. Beaujuge \\ Volker van Elsbergen \\ Jean-Charles Ribierre \\ Editors
}

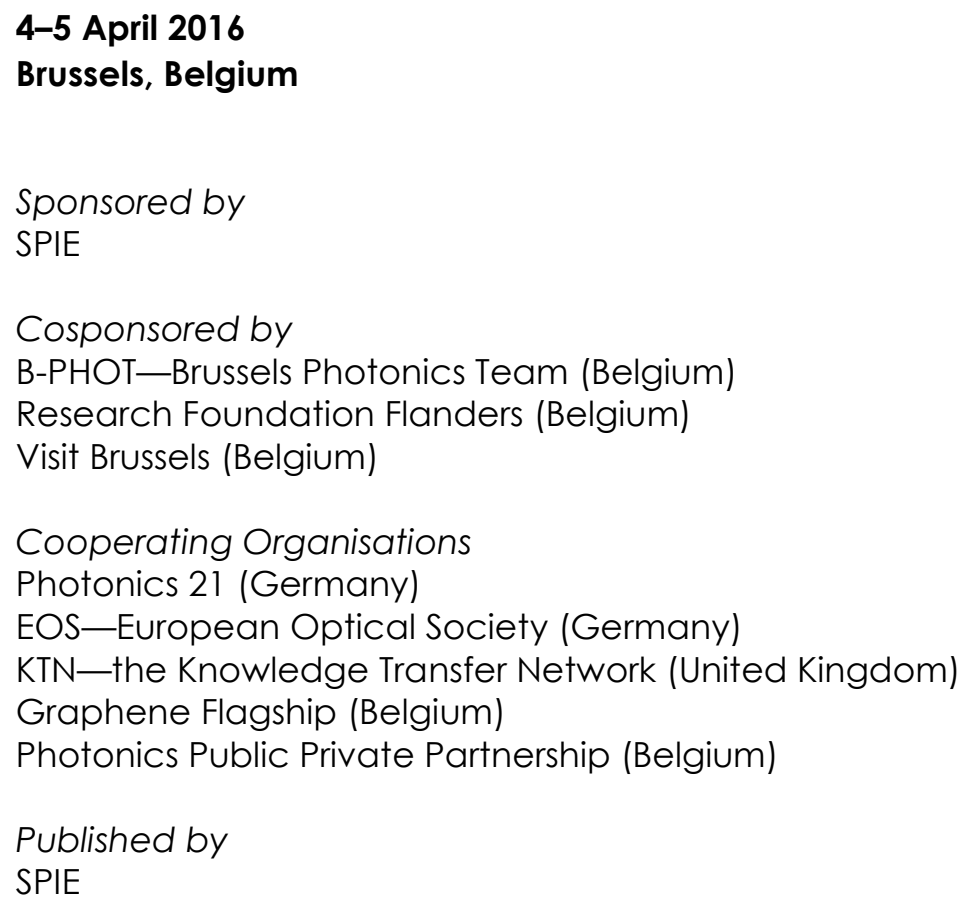


The papers in this volume were part of the technical conference cited on the cover and title page. Papers were selected and subject to review by the editors and conference program committee. Some conference presentations may not be available for publication. Additional papers and presentation recordings may be available online in the SPIE Digital Library at SPIEDigitallibrary.org.

The papers reflect the work and thoughts of the authors and are published herein as submitted. The publisher is not responsible for the validity of the information or for any outcomes resulting from reliance thereon.

Please use the following format to cite material from this book:

Author(s), "Title of Paper," in Organic Photonics VII, edited by David Cheyns, Pierre M. Beaujuge, Volker van Elsbergen, Jean-Charles Ribierre, Proceedings of SPIE Vol. 9895 (SPIE, Bellingham, WA, 2016) Six-digit Article CID Number.

ISSN: 0277-786X

ISSN: 1996-756X (electronic)

ISBN: 9781510601406

Published by

SPIE

P.O. Box 10, Bellingham, Washington 98227-0010 USA

Telephone +1 3606763290 (Pacific Time) · Fax +1 3606471445

SPIE.org

Copyright (C) 2016, Society of Photo-Optical Instrumentation Engineers.

Copying of material in this book for internal or personal use, or for the internal or personal use of specific clients, beyond the fair use provisions granted by the U.S. Copyright Law is authorized by SPIE subject to payment of copying fees. The Transactional Reporting Service base fee for this volume is $\$ 18.00$ per article (or portion thereof), which should be paid directly to the Copyright Clearance Center (CCC), 222 Rosewood Drive, Danvers, MA 01923. Payment may also be made electronically through CCC Online at copyright.com. Other copying for republication, resale, advertising or promotion, or any form of systematic or multiple reproduction of any material in this book is prohibited except with permission in writing from the publisher. The CCC fee code is 0277-786X/16/\$18.00.

Printed in the United States of America.

Publication of record for individual papers is online in the SPIE Digital Library.

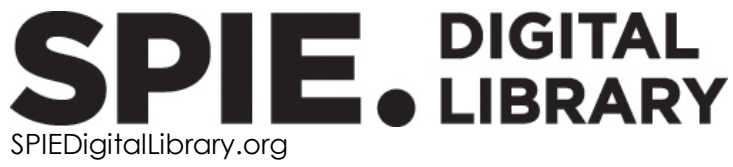

Paper Numbering: Proceedings of SPIE follow an e-First publication model, with papers published first online and then in print. Papers are published as they are submitted and meet publication criteria. A unique citation identifier (CID) number is assigned to each article at the time of the first publication. Utilization of CIDs allows articles to be fully citable as soon as they are published online, and connects the same identifier to all online, print, and electronic versions of the publication. SPIE uses a six-digit CID article numbering system in which:

- The first four digits correspond to the SPIE volume number.

- The last two digits indicate publication order within the volume using a Base 36 numbering system employing both numerals and letters. These two-number sets start with 00, 01, 02, 03, 04, $05,06,07,08,09,0 A, 0 B \ldots$ OZ, followed by 10-1Z, 20-2Z, etc.

The CID Number appears on each page of the manuscript. The complete citation is used on the first page, and an abbreviated version on subsequent pages. 


\title{
Contents
}

\author{
$\checkmark$ Authors \\ vii Conference Committee
}

\section{SENSORS AND WAVEGUIDES}

989502 Effect of non-uniform absorption and unbalanced charge carrier mobilities on dynamic response of semitransparent organic photodetector [9895-1]

989504 Analysis of cladded and uncladded dye-doped step-index polymer optical fibers [9895-4]

989505 Optical properties of bio-inspired peptide nanotubes [9895-5]

\section{ORGANIC LASERS}

989507 New concept for organic light-emitting devices under high excitations using emission from a metal-free area (Invited Paper) [9895-6]

989508 Combined optical gain and degradation measurements in DCM2 doped Tris-(8-hydroxyquinoline)aluminum thin-films [9895-7]

989509 Amplified spontaneous emission of pyranyliden derivatives in PVK matrix [9895-8]

9895 OB Electrical investigations of hybrid OLED microcavity structures with novel encapsulation methods (Best Student Paper) [9895-10]

\section{JOINT SESSION: POLYMER AND PRINTABLE MICRO-OPTICS I}

9895 OD Electronic and optical properties of functionalized polyaromatic hydrocarbons: a computational investigation on perfluorinated circumacenes [9895-27]

\section{JOINT SESSION: POLYMER AND PRINTABLE MICRO-OPTICS II}

9895 OF Dielectric impedance and optical performance of quantum dots doped OLEDs [9895-14]

9895 OG Investigation of cross-linking characteristics of novel hole-transporting materials for solution-processed phosphorescent OLEDs [9895-15] 
JOINT SESSION: ORGANIC PHOTOVOLTAICS AND CONCENTRATOR PHOTOVOLTAICS

$9895 \mathrm{OH} \quad$ Loss mechanisms in organic solar cells based on perylene diimide acceptors studied by time-resolved photoluminescence [9895-16]

POSTER SESSION

989500 Photorefractive effect in ferroelectric liquid crystal blends containing terthiophene photoconductive chiral dopants [9895-24]

$98950 Q \quad$ Study of the P3HT/PCBM interface using photoemission yield spectroscopy [9895-26] 


\title{
Authors
}

Numbers in the index correspond to the last two digits of the six-digit citation identifier (CID) article numbering system used in Proceedings of SPIE. The first four digits reflect the volume number. Base 36 numbering is employed for the last two digits and indicates the order of articles within the volume. Numbers start with 00, 01, 02, 03, 04, 05, 06, 07, 08, 09, 0A, 0B...0Z, followed by 10-1Z, 20-2Z, etc.

\author{
Ameen, Shahid, OG \\ Apter, Boris, 05 \\ Arca, F., 02 \\ Arndt, Andreas P., $\mathrm{OH}$ \\ Arrue, J., 04 \\ Ayesta, I., 04 \\ Bilal, Mühenad, $\mathrm{OH}$ \\ Bosin, Andrea, OD \\ Brückner, Robert, 07, OB \\ Cappellini, Giancarlo, OD \\ Cardia, Roberto, OD \\ Caspary, Reinhard, 08 \\ Čehovski, Marko, 08 \\ Diamant, S., 04 \\ Döring, Sebastian, 08 \\ Emmenegger, Nicolas, OF \\ Fallahpour, A. H., 02 \\ Fischer, Axel, 07 \\ Fröb, Hartmut, 07, OB \\ Gehrig, Dominik, $\mathrm{OH}$ \\ Gerhard, Marina, $\mathrm{OH}$ \\ Grzibovskis, Raitis, $0 Q$ \\ Gutsche, Stefan, 07 \\ Handelman, Amir, 05 \\ Howard, Ian A., $\mathrm{OH}$ \\ Illarramendi, M. A., 04 \\ Jiménez, F., 04 \\ Jobin, Marc, OF \\ Koch, Martin, $\mathrm{OH}$ \\ Kokars, Valdis, 09 \\ Kowalsky, Wolfgang, 08 \\ Laquai, Frédéric, $\mathrm{OH}$ \\ Lee, Changjin, OG \\ Lee, Jaemin, OG \\ Lemmer, Uli, $\mathrm{OH}$ \\ Lenk, Simone, 07 \\ Leo, Karl, 07, OB \\ Lugli, P., 02 \\ Malloci, Giuliano, OD \\ Meister, Stefan, OB \\ Mirsafaei, M., 02 \\ Palchik, O., 04 \\ Parola, I., 04 \\ Pellodi, Cédric, OF \\ Rabe, Torsten, 08 \\ Rahimi-Iman, Arash, $\mathrm{OH}$ \\ Reineke, Sebastian, 07 \\ Rosenman, Gil, 05 \\ Sasaki, Takeo, 00
}

Serra, Giovanni, OD

Slowik, Irma, 07

Vembris, Aivars, 09, 0Q

Yoshino, Masanori, 00

Zarinsh, Elmars, 09

Zubia, J., 04 
Proc. of SPIE Vol. $9895989501-6$

Downloaded From: https://www.spiedigitallibrary.org/conference-proceedings-of-spie on 26 Apr 2023 Terms of Use: https://www.spiedigitallibrary.org/terms-of-use 


\section{Conference Committee}

Symposium Chairs

Francis Berghmans, Vrije Universiteit Brussel (Belgium)

Jürgen Popp, Institut für Photonische Technologien e.V.

(Germany)

Ronan Burgess, European Commission Photonics Unit (Belgium)

Peter Hartmann, SCHOTT, AG (Germany)

Honorary Symposium Chair

Hugo Thienpont, Vrije Universiteit Brussel (Belgium)

Conference Chairs

David Cheyns, IMEC (Belgium)

Pierre M. Beaujuge, King Abdullah University of Science and Technology (Saudi Arabia)

Volker van Elsbergen, Philips Technologie GmbH (Germany)

Jean-Charles Ribierre, Kyushu University (Japan)

Conference Programme Committee

Heinrich Becker, Merck OLED Materials GmbH (Germany)

David Beljonne, Universiteit de Mons (Belgium)

Paul W. M. Blom, Universiteit of Groningen (Netherlands)

Donal D. C. Bradley, Imperial College London (United Kingdom)

Franco Cacialli, University College London (United Kingdom)

Enrico Da Como, Ludwig-Maximilians-Universität München (Germany)

Richard H. Friend, University of Cambridge (United Kingdom)

Alan J. Heeger, University of California, Santa Barbara (United States)

Paul L. Heremans, IMEC (Belgium)

René A. J. Janssen, Technische Universiteit Eindhoven (Netherlands)

Junji Kido, Yamagata University (Japan)

Jang-Joo Kim, Seoul National University (Korea, Republic of)

Guglielmo Lanzani, Politecnico di Milano (Italy)

Karl Leo, Fraunhofer-Einrichtung für Organik, Materialien und

Elektronische Bavelemente COMEDD (Germany)

Niyazi Serdar Sariciftci, Johannes Kepler University Linz (Austria)

Paul van der Schaaf, BASF Schweiz AG (Switzerland)

Chung-Chih Wu, National Taiwan University (Taiwan) 


\section{Session Chairs}

Sensors and Waveguides

David Cheyns, IMEC (Belgium)

\section{Organic Lasers}

Jean-Charles Ribierre, Kyushu University (Japan)

Joint Session: Polymer and Printable Micro-Optics I

Volker van Elsbergen, Philips Technologie GmbH (Germany)

Joint Session: Polymer and Printable Micro-Optics II

Hans Zappe, Universität of Freiburg (Germany)

Joint Session: Organic Photovoltaics and Concentrator Photovoltaics

David Cheyns, IMEC (Belgium) 